\title{
Robotassistert laparoskopisk kirurgi ved gynekologisk sykdom
}

\section{Robotassistert laparoskopisk radikal hysterektomi ved livmorhalskreft har vært utført ved Radiumhospitalet siden 2005.}

Et robotkirurgisk system, kalt da Vinci-systemet, er de siste årene tatt i bruk i gynekologisk kirurgi. Det har vist seg nyttig ved bl.a. myomektomi, tubal reanastomose, kompleks hysterektomi og behandling av omfattende endometriose og sakrokolpo-

peksi. Innen gynekologisk onkologi er roboten blitt brukt til radikal hysterektomi ved livmorhalskreft og ved paraaortal lymfadenektomi, trakelektomi, eggstokktransposisjon, endometriekreft og eggstokkreft.

Vi rapporterte den første robotassisterte

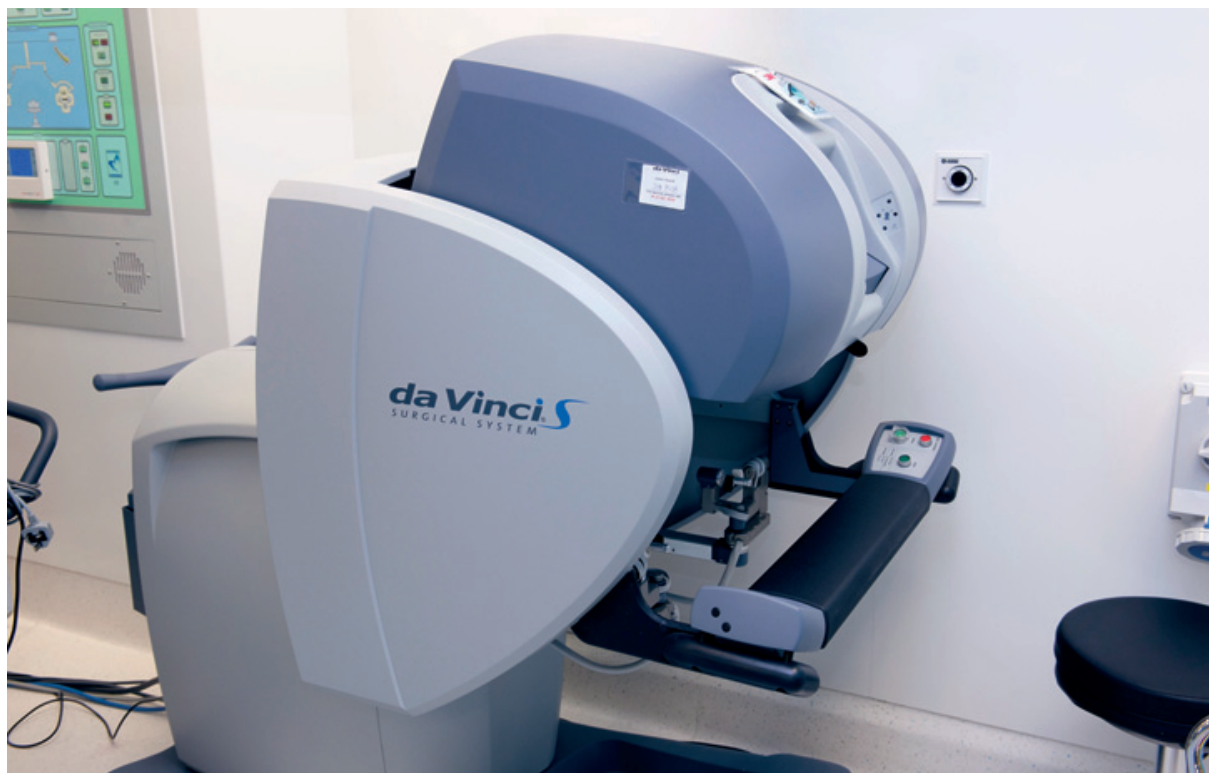

Illustrasjonsfoto Science Photo Library/NTB Scanpix

\section{Artrose er mer enn slitasje}

\section{Komplementsystemet er aktivert i artrotiske ledd. Musemodeller viser hvordan komplementindu- sert inflammasjon kan være viktig i patogenesen.}

Artrose kalles gjerne slitasjegikt, men ny forskning tyder på at inflammasjon kan være viktig i sykdomsutviklingen (1). I sammenlikning med synovialvæske fra friske ledd viste en proteomscreening at artrotisk leddvæske hadde økt konsentrasjon av komplementproteiner. Tilsvarende var det høyere uttrykk for komplementrelaterte transkripter i synovialmembranene fra artrosepasientene. I artrosemodeller utviklet mus som var defekte på ulike steder i komplementsystemet (faktor C5 og faktor C6), mindre artrose enn villtypemusene. Mus som manglet en laparoskopiske radikale hysterektomi og bekkenlymfadenektomi i 2006 (1). Siden er det publisert en rekke artikler om disse inngrepene $(2,3)$. Vi har vist at robotassisterte prosedyrer er teknisk gjennomførbare, trygge og gir tilfredsstillende histopatologiske resultater. Vi har også funnet at robotassistert laparoskopisk radikal hysterektomi er assosiert med mindre blodtap og kortere sykehusopphold sammenliknet med laparoskopi og laparotomi (4). Vi mener at dette er en lovende teknikk som vil bli mye brukt i gynekologisk onkologi fremover.

\section{Bilal M. Sert}

bsert@online.no

Oslo universitetssykehus, Radiumhospitalet

\section{Litteratur \\ 1. Sert BM, Abeler VM. Robotic-assisted laparosco- pic radical hysterectomy (Piver type III) with pelvic node dissection-case report. Eur J Gynaecol Onco 2006; 27: 531-3. \\ 2. Cho JE, Nezhat FR. Robotics and gynecologic oncology: review of the literature. J Minim Invasive Gynecol 2009; 16: 669-81. \\ 3. Sert B, Abeler V. Robotic radical hysterectomy in early-stage cervical carcinoma patients, compa- ring results with total laparoscopic radical hyste- rectomy cases. The future is now? Int J Med Robot 2007; 3: 224-8 \\ 4. Sert MB, Abeler V. Robot-assisted laparoscopic radical hysterectomy: comparison with total laparoscopic hysterectomy and abdominal radical hysterectomy; one surgeon's experience at the Norwegian Radium Hospital. Gynecol Oncol 2011; 121: $600-4$}

hemmer av det terminale lytiske komplementkomplekset (MAC, membran-attakkkomplekset, C5-9), ble kraftigere angrepet. Bruskkomponenter aktiverte komplementsystemet. Komplementkomplekset stimulerte kondrocytter til å skille ut matriksnedbrytende enzymer og inflammatoriske mediatorer. Hva kan dette bety for utviklingen av artrosebehandling?

- Dette er svært interessante funn, sier professor Lars Nordsletten, Ortopedisk avdeling, Oslo universitetssykehus. - Fra før vet vi at repetert blødning $i$ et ledd er skadelig for brusken, og trombin har vært ansett som et viktig enzym som kunne aktivere de mer spesifikke brusknedbrytende proteasene. At komplement kan være avgjørende for brusknedbrytningen, kan derfor potensielt gi en mulighet for terapi - ved å blokkere MAC-produksjon i leddene.

Det er ikke nerver i brusk, og vi har ikke gode biomarkører eller bildefremstillinger av brusk. Dette gjør det vanskelig å utvikle god behandling mot artrose. For leddgikt og osteoporose, derimot, finnes det gode biomarkører og bildefremstillinger, og det er gjort store terapeutiske fremskritt. Dyremodeller med knockoutmus kan brukes til å teste ut behandling som så kan prøves på artrosepasienter senere, sier Nordsletten.

Haakon B. Benestad

h.b.benestad@medisin.uio.no

Universitetet i Oslo

\section{Litteratur}

Wang Q, Rozelle AL, Lepus CM et al. Identification of a central role for complement in osteoarthritis. Nat Med 2011; 17: 1674-9. 